\title{
Substitution of ractopamine by safflower or coconut oil as an additive in finishing pig diets
}

\author{
Clara Viviane Silva da $\operatorname{Costa}^{1}$ (D) José Aparecido Moreira ${ }^{2}$ Andreza Lourenço Marinho ${ }^{3^{*}}$ (iD \\ Natália Rocha Silva ${ }^{1}$ Myllena Emelly de Paiva Carmo ${ }^{1}$ Adriana Margarida Zambotto Ramalho ${ }^{3}$ \\ Emerson Moreira Aguiar ${ }^{1}$ (D) Janete Gouveia de Souza ${ }^{1}$ Elisanie Neiva Magalhães Teixeira ${ }^{1}$
}

${ }^{1}$ Programa de Pós-graduação em Produção Animal, Universidade Federal do Rio Grande do Norte (UFRN), Natal, RN, Brasil. ${ }^{2}$ Programa de Pós-graduação em Produção Animal, Universidade Federal do Rio Grande do Norte (UFRN), Natal, RN, Brasil. ${ }^{3}$ Programa Nacional de Pós-doutorado (PNPD/CAPES), Universidade Federal do Rio Grande do Norte (UFRN), 59080-110, Natal, RN, Brasil. E-mail: andrezazte@hotmail.com. *Corresponding author.

ABSTRACT: The objective of this study was to explore the substitution of ractopamine by coconut or safflower oil in finishing pig diets. The study included 24 crossbred barrows weighing $78.00 \pm 8.76 \mathrm{~kg}$ distributed in a randomized block design with four treatments and six replicates composed of: basal ration (BR), BR $+10 \mathrm{ppm}$ ractopamine, BR + four $1 \mathrm{~g}$ capsules of safflower oil, and BR + four $1 \mathrm{~g}$ capsules of coconut oil. Performance evaluation showed that safflower oil, ractopamine, and coconut oil supplementation had a significant effect $(P<0.05)$ on weight gain and feed conversion. Carcass-related variables were also affected by the treatments $(P<0.05)$, with fat thickness 3 (FT3) reduced by the use of safflower oil, ractopamine, and coconut oil. Rib eye area was positively affected $(P<0.05)$ by diet, with ractopamine, coconut oil, and safflower oil supplementation treatments showing higher values than control diet treatment. The diets also affected fatty acid profiles $(P<0.05)$, with decreased myristic acid content in animals supplemented with ractopamine and safflower oil and increased deposition of palmitoleic and oleic acids in animals supplemented with coconut oil and safflower oil, respectively. Results suggested that both safflower oil and coconut oil can be used as substitutes for ractopamine.

Key words: $\beta$-adrenergic, fat deposition, lipid metabolism, vegetable oils.

Substituição da ractopamina por óleo de cártamo ou óleo de coco como aditivos em dietas para suínos em terminação

RESUMO: Objetivou-se avaliar a substituição da suplementação da ractopamina pelo uso dos óleos de coco ou cártamo nas dietas de suínos

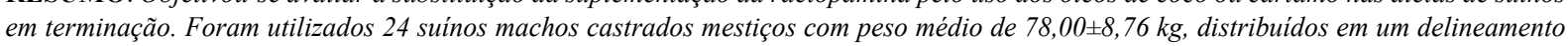
de blocos casualizados, contendo quatro tratamentos e seis repetições compostos por: Ração Basal (RB); RB + 10 ppm de ractopamina; RB + 4 cápsulas de 1 grama cada de óleo de cártamo e RB + 4 cápsulas de 1 grama cada de óleo de coco. Na avaliação do desempenho foi observado o efeito $(P<0,05)$ da suplementação das dietas com óleo de cártamo, ractopamina e coco no ganho de peso e conversão alimentar. As variáveis relacionadas com as carcaças também foram afetadas pelos tratamentos $(P<0,05)$, sendo a espessura de toucinho 3 (ET3) reduzida pelo uso do óleo de cártamo, ractopamina e coco. Na avaliação da área de olho de lombo foram observados efeitos positivos (P<0,05), com maiores valores para os tratamentos suplementados com ractopamina, óleo de coco e com óleo de cártamo, quando comparados com a dieta controle. As dietas também afetaram o perfil dos ácidos graxos $(P<0,05)$ de forma positiva, com a redução do ácido míristico do toucinho nas dietas com ractopamina e óleo de cártamo e aumento na deposição dos ácidos graxos palmitoleico e oleico do lombo nas dietas suplementadas com óleo de coco e cártamo, respectivamente. Conclui-se que tanto o óleo de coco quanto o de cártamo podem ser utilizados como substitutos da ractopamina.

Palavras-chave: $\beta$-adrenérgico, deposição de gordura, metabolismo lipídico, óleos vegetais.

\section{INTRODUCTION}

In recent years, Brazil has been consolidated as one of the major global suppliers of animal protein, including beef, pork, or poultry; it is the world's largest exporter of beef and chicken and ranks fourth in pork production and exports, according to the Brazilian Animal Protein Association (ABPA, 2018).

Approximately $81.5 \%$ of the pork produced in Brazil is intended for the domestic market, and the surplus is exported to countries such as Singapore, Hong Kong, China, and Russia, 
representing approximately $18.5 \%$ of world exports (ABPA, 2018). However, important trading partners such as China and Russia have restricted the purchase of animals fed with ractopamine.

Ractopamine is used in more than 20 countries such as the USA, Canada, Australia, and almost all of Latin America (FERREIRA et al., 2011) to decrease the rate of lipid deposition and increase the amount of lean meat in carcasses, two characteristics expected by the consumer market.

People worldwide are concerned about obesity, which is associated with the onset of many conditions, especially cardiovascular diseases (SANTOS et al., 2013). Many articles in the literature suggested that coconut and safflower oils are efficientin reducing body fat in humans and Wistar rats (ASSUNÇÃO et al., 2009; LIAU et al., 2011; CAMPANELLA et al., 2014).

Safflower oil is rich in long-chain fatty acids, especially omega-6 fatty acids, and has thermogenic properties that can increase satiety (CAMPANELLA et al., 2014). Coconut oil contains medium-chain fatty acids, which are absorbed and used in metabolic processes and not deposited in adipocytes (FIGUEIREDO-SILVA, 2012).

Studies by BLANKSON et al. (2000) using safflower oil in animal diets showed increased lean mass and decreased body fat, in addition to reducing glycerol and triacylglycerol concentration and markedly decreasing fat mass in obese humans. ASSUNÇÃO et at. (2009) studied the effect of coconut oil on humans and reported decreased abdominal fat. In this context, the objective of this research was to evaluate the substitution of ractopamine supplementation by safflower or coconut oil in finishing pig diets regarding performance, carcass quality, and carcass fatty acid profile.

\section{MATERIALS AND METHODS}

This study included 24 crossbred (Landrace $\times$ Large White $\times$ Pietrain) barrows with a mean weight of $78.00 \pm 8.76 \mathrm{~kg}$, distributed in a randomized block design by weight into four treatments [basal ration (BR), ractopamine, safflower oil, and coconut oil] and six replicates with one animal in each experimental unit, totaling 24 plots. The animals were kept in individual concrete-floored stalls measuring $2.76 \times 1.85 \mathrm{~m}$, with pacifier drinkers and semi-automatic feeders.

The experimental diets were formulated following the recommendations by ROSTAGNO et al. (2011). The basal diet was formulated with corn, soybean meal, vegetable oil, and commercial premix for finishing pigs, with treatments consisting of $\mathrm{BR}, \mathrm{BR}+10 \mathrm{ppm}$ ractopamine, $\mathrm{BR}+$ four $1 \mathrm{~g}$ capsules of safflower oil, and BR + four $1 \mathrm{~g}$ capsules of coconut oil, as presented in table 1 .

The capsules were administered when the animals were fed, after an adaptation period of 2 days, considering the recommendation for humans of four capsules a day based on body weight (60 to $100 \mathrm{~kg}$ ). The capsules were administered in two periods, two capsules at 8 am and two capsules at 4 pm, totaling four capsules a day, appropriate for the mean animal weight of 78 to $100 \mathrm{~kg}$ during the experimental period.

The animals were weighed at the beginning and end of the 28-day experiment for performance evaluation. All feed provided and feeder leftovers and waste were analyzed to estimate feed consumption and conversion and to calculate weight gain.

At the end of the experimental period, the animals were subjected to an 8-hour fast for solids and four allowed a pre-slaughter rest period, totaling a 12-hourfast. The animals were slaughtered following humane slaughter rules - stunned by electronarcosis; and subsequently, exsanguinated.

The carcasses were weighed to obtain the hot carcass weight (HCW), and the initial $\mathrm{pH}$ (45 min after slaughter) was measured in the longissimus dorsi muscle of the left half carcass using a portable $\mathrm{pH}$ meter with an insertion electrode. The carcasses were subsequently sawn in half and stored in a cold chamber for $24 \mathrm{~h}$ at approximately $4{ }^{\circ} \mathrm{C}$. After cooling, the carcasses were weighed to obtain the cold carcass weight $(\mathrm{CCW})$. Weight loss during cooling was obtained from the difference between $\mathrm{HCW}$ and $\mathrm{CCW}$. Then the final $\mathrm{pH}$ of the left half carcass was measured $(24 \mathrm{~h}$ after slaughter), and carcass length was measured according to the Brazilian carcass classification method (ABCS, 1973). Carcass yield was calculated using the final weight in pre-transport fasting period, $\mathrm{HCW}$, and CCW.

Rib eye (longissimus dorsi) area (REA) and fat area were determined using calipersto measure the sawn carcasses at the height of the last rib (P2) on a tracing paper drawing (ABCS, 1973). The meat: fat ratio was obtained by dividing the respective values of area.

Longissimus dorsi depth and fat thickness were measured at $\mathrm{P} 2$ at the junction of the last thoracic vertebra and the first lumbar vertebra, $6.5 \mathrm{~cm}$ from the midline of the carcass. The values of $\mathrm{HCW}, \mathrm{CCW}$, fat thickness (FT) at P2, and loin depth (LD) were used to calculate meat yield $[60-(\mathrm{FTP} 2 \times 0.058)+(\mathrm{LD} \times$ $0.1)]$ and the amount of meat in the carcass $[(\mathrm{CCW} \times$ meat yield)/100] using the equations described by BRIDI \& SILVA (2009). 
Table 1 - Basal ration composition for finishing pigs.

\begin{tabular}{|c|c|}
\hline Ingredient (\%) & Basal ration \\
\hline Corn $7.8 \%$ & 73.1518 \\
\hline Soybean meal $45 \%$ & 15.1302 \\
\hline Wheat bran $15.1 \%$ & 6.4555 \\
\hline Premix $^{1}$ & 3.0000 \\
\hline Soybean oil & 2.0000 \\
\hline L-Lysine & 0.2195 \\
\hline L-Threonine & 0.0431 \\
\hline Calculated values & 100 \\
\hline Crude protein $(\%)$ & 13.53 \\
\hline $\mathrm{ME}(\mathrm{Kcal} / \mathrm{kg})$ & 3230 \\
\hline Available phosphorus (\%) & 0.11 \\
\hline Sodium $(\%)$ & 0.15 \\
\hline Chlorine (\%) & 0.04 \\
\hline Digestible lysine (\%) & 0.72 \\
\hline Digestible methionine (\%) & 0.23 \\
\hline Methionine + digestible cystine $(\%)$ & 0.41 \\
\hline Digestible threonine (\%) & 0.48 \\
\hline Digestible tryptophan (\%) & 0.13 \\
\hline Digestible valine (\%) & 0.56 \\
\hline
\end{tabular}

${ }^{1}$ Guarantee levels per kg of product: calcium (min) $235 \mathrm{~g} / \mathrm{kg}$; calcium (max) $240 \mathrm{~g} / \mathrm{kg}$; phosphorus (min) $34.67 \mathrm{~g} / \mathrm{kg}$; sodium (min) 585 $\mathrm{g} / \mathrm{kg}$; iron $(\mathrm{min}) 3.389 \mathrm{mg} / \mathrm{kg}$; copper $(\mathrm{min}) 4.000 \mathrm{mg} / \mathrm{kg}$; manganese (min) $1.333 \mathrm{mg} / \mathrm{kg}$; zinc (min) $3.333 \mathrm{mg} / \mathrm{kg} ; \mathrm{iodine}(\mathrm{min}) 33.33$ $\mathrm{mg} / \mathrm{kg}$; cobalt $(\mathrm{min}) 6.86 \mathrm{mg} / \mathrm{kg}$; selenium (min) $10 \mathrm{mg} / \mathrm{kg}$; vitamin A (min) $116.800 \mathrm{IU} / \mathrm{kg}$; vitamin D3 (min) $25.000 \mathrm{IU} / \mathrm{kg}$; vitamin E (min) $833.33 \mathrm{IU} / \mathrm{kg}$; vitamin K3 (min) $40 \mathrm{mg} / \mathrm{kg}$; vitamin B1 (min) $16.7 \mathrm{mg} / \mathrm{kg}$; vitamin B2 (min) $66.7 \mathrm{mg} / \mathrm{kg}$; niacin $(\mathrm{min}) 500 \mathrm{mg} / \mathrm{kg}$; pathogenicacid ( $\min ) 267 \mathrm{mg} / \mathrm{kg}$; vitamin B6 (min) $16.7 \mathrm{mg} / \mathrm{kg}$; folicacid (min) $5 \mathrm{mg} / \mathrm{kg}$; biotin (min) $3.33 \mathrm{mg} / \mathrm{kg}$; vitamin B12 (min) $333 \mathrm{mcg} / \mathrm{kg}$; phytase $16.66 \mathrm{FTU} / \mathrm{g}$; BHT $133 \mathrm{mg} / \mathrm{kg}$; bacitracin (min) $1.883 \mathrm{mg} / \mathrm{kg}$; choline (min) $3.338 \mathrm{mg} / \mathrm{kg}$; andfluorine (max) 332 $\mathrm{mg} / \mathrm{kg}$.

Fat thickness was measured at three different points of the carcass using calipers-at the height of the first rib (FT1); at the height of the last rib (FT2), measured at the junction of the last thoracic vertebra and the first lumbar vertebra; and at the junction of the last two lumbar vertebrae (FT3), both measured perpendicularly to the dorsal-lumbar line. The mean fat thickness (MFT) of the carcass was calculated using the three fat measurements. Qualitative and $\mathrm{pH}$ parameters were assessed using muscle color and marbling, measured using the 0 to 6 scale recommended by the NATIONAL PORK PRODUCERS COUNCIL (NPPC, 1999) and the MEAT EVALUATION HANDBOOK (2001).

Loin and fat samples were collected, identified, and sent to the Animal Nutrition Laboratory for fatty acid profile evaluation using gas chromatography, according to the methodology proposed by BLIGH \& DYER (1959). After extraction, the material was saponified and subjected to methylation, according to the methodology reported by HARTMAN \& LAGO (1973). Statistical Analysis System software (2004) was used to calculate the analysis of variance, and the means were compared using Duncan's test at 5\% probability.

\section{RESULTS AND DISCUSSION}

The performance evaluation showed no effect on the initial weight, final weight, and daily feed intake $(\mathrm{P}>0.05)$, but there were effects on daily weight gain and feed conversion $(\mathrm{P}<0.05)$ (Table 2$)$.

Animals that consumed a diet supplemented with ractopamine showed the highest values for daily weight gain, which did not differ from those shown by the animals supplemented with coconut oil. Animals receiving ractopamine and safflower oil supplementation showed the highest feed conversion values, which did not differ from the values observed in the animals supplemented with coconut oil.

Ciência Rural, v.50, n.6, 2020. 
Table 2 - Performance evaluation of barrows supplemented with ractopamine, safflower oil, and coconut oil.

\begin{tabular}{|c|c|c|c|c|c|c|}
\hline \multirow[t]{2}{*}{ Parameter $(\mathrm{Kg})$} & \multicolumn{4}{|c|}{------------------------------------------------'Treatment------------------------------------------ } & \multirow[t]{2}{*}{$\mathrm{P}$} & \multirow[t]{2}{*}{${ }^{1} \mathrm{CV}(\%)$} \\
\hline & Basal ration & Ractopamine & Safflower & Coconut & & \\
\hline Initial weight) & 79.333 & 79.500 & 78.500 & 77.833 & 0.75 & 3.78 \\
\hline Final weight) & 103.000 & 106.167 & 101.000 & 105.833 & 0.39 & 5.61 \\
\hline Daily consumption & 3.27 & 3.14 & 2.78 & 3.29 & 0.20 & 14.03 \\
\hline Daily weight gain & $0.92^{\mathrm{b}}$ & $1.06^{\mathrm{a}}$ & $0.91^{\mathrm{b}}$ & $1.01^{\mathrm{ab}}$ & 0.05 & 10.10 \\
\hline Feed conversion & $3.76^{\mathrm{a}}$ & $3.09^{\mathrm{b}}$ & $3.25^{\mathrm{b}}$ & $3.35^{\mathrm{ab}}$ & 0.05 & 11.43 \\
\hline
\end{tabular}

Means followed by different letters on the same line are significantly different by Duncan's test at $5 \%$ probability level. ${ }^{1} \mathrm{CV}$ : Coefficient of variation.

Performance results showed that supplementation with oils was similarly effective in improving animal performance as ractopamine; therefore, it is possible to replace the chemical additive (ractopamine) with the natural additives.

Coconut oil is rich in medium-chain fatty acids that reduce body fat (ASSUNÇÃO et al., 2009; LIAU et al., 2011) and increase the proportion of lean mass in the carcass, justifying the increased weight gain of the animals evaluated. Improved feed conversion with the use of safflower oil may be associated with the thermogenic effect of this oil owing to the presence of long-chain fatty acids, which increase satiety (CAMPANELLA et al., 2014).

There were no differences $(\mathrm{P}>0.05)$ in carcass yield, carcass length, leg weight, FT1 and 2, MFT, FT at P2, LD, fat area, meat: fat ratio, meat yield, and amount of meat in the animals evaluated (Table 3 ).

Animals supplemented with safflower oil showed lower fat thickness $(\mathrm{P}<0.05)$, which did not differ from that observed in animals supplemented with ractopamine and coconut oil. This finding confirmed the effectiveness of the tested products in reducing fat deposition and the superiority of safflower oil among the treatments used, especially when considering fat thickness values (FT1 and 2, P2, and fat area);safflower oil supplementation, despite not having a significant effect, was the treatment that showed less fat deposition than the other treatments.

According to LUCAS et al. (2016), lower fat deposition with the use of safflower oil may be related to its composition; safflower oil contains approximately $70 \%$ linoleic acid, which may inhibit the action of the enzyme lipoprotein lipase (LPL) responsible for lipid deposition in adipocytes. OBSEN et al. (2012) state that a high amount of LPL in the body leads to high lipid storage in fat cells, and when the activity of this enzyme is blocked, lipid transfer into fat cells is inhibited, forcing the body to use its fat reserve as an energy source.

Ractopamine treatments resulted in higher REA values $(\mathrm{P}<0.05)$, with a similar effect observed in animals supplemented with coconut oil and safflower oil. ALMEIDA et al. (2010) reported that increased REA is associated with increased protein synthesis in skeletal muscles and decreased amino acid catabolism. This response associated with ractopamine supplementation may be correlated with increased REA in pigs, suggesting that ractopamine supplementation results in carcasses with increased percentages of lean meat, decreased lipid synthesis in adipose tissue, and increased protein synthesis in muscles.

Considering that there was no difference in REA among animals treated with ractopamine, coconut oil, and safflower oil and that animals supplemented with coconut and safflower oils showed less fat deposition, these oils may have the potential to replace ractopamine.

There were no differences $(\mathrm{P}>0.05)$ in the parameters meat quality, initial $\mathrm{pH}$, final $\mathrm{pH}$, color, marbling, water loss in cooling among any of the evaluated treatments (Table 4). A study by COSTA E SILVA et al. (2017) on the inclusion of $7.5 \mathrm{ppm}$ of ractopamine in the diet of female, castrated, and immunocastrated pigs showed no differences in meat quality parameters.

Palmitoleic acid concentration in the loin differed $(\mathrm{P}<0.05)$ among treatments; the animals supplemented with coconut oil showed the highest palmitoleic acid concentrations compared to the reference diet, which did not differ from those in animals supplemented with safflower oil and ractopamine (Table 5). 
Table 3 - Mean carcass characteristics of pigs supplemented with ractopamine, safflower oil, and coconut oil.

\begin{tabular}{|c|c|c|c|c|c|c|}
\hline \multirow[t]{2}{*}{ Parameter } & \multicolumn{4}{|c|}{ 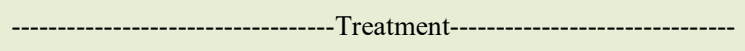 } & \multirow[t]{2}{*}{$\mathrm{P}$} & \multirow[t]{2}{*}{${ }^{1} \mathrm{CV}(\%)$} \\
\hline & Basal ration & Ractopamine & Safflower & Coconut & & \\
\hline Carcass yield (\%) & 79.22 & 80.13 & 79.94 & 80.47 & 0.73 & 2.61 \\
\hline Carcass length (cm) & 99.67 & 99.67 & 98.17 & 99.17 & 0.89 & 3.78 \\
\hline Leg weight (kg) & 12.50 & 13.19 & 12.68 & 13.02 & 0.52 & 6.78 \\
\hline${ }^{2} \mathrm{FT} 1(\mathrm{~mm})$ & 4.17 & 4.19 & 3.66 & 4.19 & 0.13 & 10.79 \\
\hline${ }^{3} \mathrm{FT} 2(\mathrm{~mm})$ & 2.81 & 2.96 & 2.63 & 2.66 & 0.55 & 15.71 \\
\hline${ }^{4} \mathrm{FT} 3(\mathrm{~mm})$ & $2.79^{\mathrm{a}}$ & $2.55^{\mathrm{ab}}$ & $2.24^{\mathrm{b}}$ & $2.73^{\mathrm{ab}}$ & 0.05 & 16.09 \\
\hline${ }^{5} \mathrm{MFT}(\mathrm{mm})$ & 3.26 & 3.23 & 2.85 & 3.19 & 0.13 & 10.13 \\
\hline${ }^{6} \mathrm{P} 2(\mathrm{~cm})$ & 1.92 & 1.67 & 1.50 & 1.77 & 0.34 & 22.72 \\
\hline${ }^{7} \mathrm{LD}\left(\mathrm{cm}^{2}\right)$ & 5.63 & 6.28 & 5.83 & 6.07 & 0.21 & 8.88 \\
\hline${ }^{8} \operatorname{REA}\left(\mathrm{mm}^{2}\right)$ & $40.34^{\mathrm{b}}$ & $47.53^{\mathrm{a}}$ & $43.18^{\mathrm{ab}}$ & $43.63^{\mathrm{ab}}$ & 0.05 & 11.68 \\
\hline Fat area $\left(\mathrm{mm}^{2}\right)$ & 23.32 & 24.48 & 18.27 & 22.48 & 0.46 & 31.49 \\
\hline Meat:fat ratio $\left(\mathrm{mm}^{2}\right)$ & 1.93 & 2.07 & 2.50 & 2.01 & 0.30 & 25.54 \\
\hline Meat yield (\%) & 60.40 & 60.46 & 60.43 & 60.45 & 0.50 & 0.92 \\
\hline Amount of meat in the carcass $(\%)$ & 48.39 & 50.76 & 48.13 & 50.03 & 0.45 & 6.51 \\
\hline
\end{tabular}

Means followed by different letters on the same line are significantly different by Duncan's test at $5 \%$ probability level; ${ }^{1} \mathrm{CV}$ : Coefficient of variation; ${ }^{2} \mathrm{FT} 1$ : fat thickness measured on the first rib; ${ }^{3} \mathrm{FT} 2$ : fat thickness measured on the last rib; ${ }^{4} \mathrm{FT} 3$ : fat thickness measured at the last lumbar vertebra; ${ }^{4} \mathrm{MFT}$ : mean of fat thickness values FT1, FT2, and FT3; ${ }^{6} \mathrm{P} 2$ : fat thickness measured at $6.5 \mathrm{~cm}$ from the dorsal-lumbar line of the last rib; ${ }^{7} \mathrm{LD}$ : loin depth measured in the longissimus dorsi muscle; ${ }^{8} \mathrm{REA}$ : rib eye area.

Palmitoleic acid, also known as $\omega 7$, is not synthesized by the human body; therefore, its dietary supplementation is necessary. It has recently been identified as a lipokine, a lipid hormone synthesized and secreted by adipose tissue in humans, acting as a hormonal signal in organs such as the liver and pancreas; increasing insulin sensitivity; modulating inflammatory and metabolic processes; and controlling systemic, lipid, and glucose metabolism (BOLSONI-LOPES et al., 2014). The authors also reported a potentiating of metabolic flow of energy pathways associated with inhibition of energy storage pathways, suggesting that $\mathrm{C} 16: 1$ regulates lipolysis via a mechanism dependent on peroxisome proliferatoractivated receptor $\alpha$, a subtype of receptors activated by peroxisome proliferators and linked to the hepatic oxidation of fatty acids.

Oleic acid concentrations in the loin also differed $(\mathrm{P}<0.05)$, with the animals supplemented with safflower oil showing the highest concentrations,

Table 4 - Mean carcass quality characteristics of pigs supplemented with ractopamine, safflower oil, and coconut oil: initial and final $\mathrm{pH}$, initial temperature (ITEMP), final temperature (FTEMP), meat color and marbling (MAR), water loss by cooling (WLC).

\begin{tabular}{|c|c|c|c|c|c|c|}
\hline \multirow[t]{2}{*}{ Parameter } & \multicolumn{4}{|c|}{ 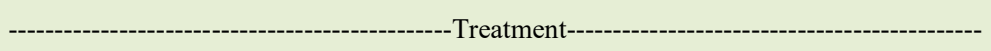 } & \multirow[t]{2}{*}{$\mathrm{P}$} & \multirow[t]{2}{*}{${ }^{1} \mathrm{CV}(\%)$} \\
\hline & Basal ration & Ractopamine & Safflower & Coconut & & \\
\hline $\mathrm{pH} 45$ min postmortem & 6.87 & 6.90 & 6.76 & 6.77 & 0.72 & 3.61 \\
\hline $\mathrm{pH} 24 \mathrm{~h}$ postmortem & 5.97 & 5.85 & 5.83 & 5.90 & 0.41 & 2.57 \\
\hline Color $^{2}$ & 3.00 & 2.67 & 2.83 & 2.83 & 0.76 & 18.60 \\
\hline Marbling $^{2}$ & 2.83 & 3.33 & 2.50 & 3.17 & 0.30 & 26.60 \\
\hline WLC (g) & 1.87 & 2.03 & 2.07 & 2.18 & 0.82 & 28.50 \\
\hline
\end{tabular}

${ }^{1} \mathrm{CV}$ : Coefficient of variation; ${ }^{2}$ Scale of points from 1 to 6 by the NATIONAL PORK PRODUCERS COUNCIL (NPPC, 1999) and MEAT EVALUATION HANDBOOK (2001). 
Table 5 - Fatty acid composition of the longissimus dorsi muscle and adipose tissue (fat) of pigs supplemented with ractopamine, safflower oil, and coconut oil.

\begin{tabular}{|c|c|c|c|c|c|c|}
\hline \multirow[t]{2}{*}{ Fatty acid $(\mu \mathrm{g} / \mathrm{g})$} & \multicolumn{4}{|c|}{----------------------------------------- Treatment------------------------------------ } & \multirow[t]{2}{*}{$\mathrm{P}$} & \multirow[t]{2}{*}{${ }^{1} \mathrm{CV}(\%)$} \\
\hline & Basal ration & Ractopamine & Safflower & Coconut & & \\
\hline \multicolumn{7}{|c|}{ 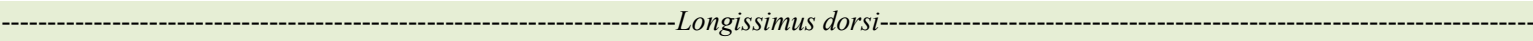 } \\
\hline Lauric (C12: 0) & 0.10 & 0.10 & 0.10 & 0.11 & 0.73 & 12.87 \\
\hline Myristic (C14: 0) & 1.16 & 1.14 & 1.29 & 1.28 & 0.34 & 14.38 \\
\hline Palmitic (C16: 0) & 23.41 & 24.27 & 24.99 & 24.71 & 0.30 & 6.02 \\
\hline Palmitoleic (C16: 1) & $2.58^{\mathrm{b}}$ & $2.74^{\mathrm{ab}}$ & $2.82^{\mathrm{ab}}$ & $3.25^{\mathrm{a}}$ & 0.05 & 16.81 \\
\hline Oleic (C18: 1n9) & $32.70^{\mathrm{b}}$ & $34.70^{\mathrm{ab}}$ & $38.79^{\mathrm{a}}$ & $36.63^{\mathrm{ab}}$ & 0.05 & 12.83 \\
\hline Linoleic (C18: 2n6) & 14.24 & 13.35 & 10.90 & 11.54 & 0.23 & 23.84 \\
\hline Linolenic (C18: 3n3) & 0.48 & 0.44 & 0.53 & 0.48 & 0.76 & 27.15 \\
\hline Arachidonic (C20: 4n6) & 3.13 & 2.84 & 2.09 & 2.42 & 0.33 & 38.46 \\
\hline \multicolumn{7}{|c|}{ 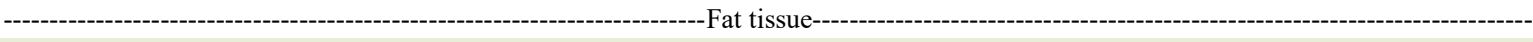 } \\
\hline Lauric (C12: 0) & 0.21 & 0.20 & 0.16 & 0.30 & 0.33 & 59.10 \\
\hline Myristic (C14: 0) & $1.47^{\mathrm{a}}$ & $1.32^{\mathrm{b}}$ & $1.33^{\mathrm{b}}$ & $1.49^{\mathrm{a}}$ & 0.05 & 6.27 \\
\hline Palmitic (C16: 0) & 19.09 & 19.16 & 17.36 & 17.55 & 0.77 & 21.27 \\
\hline Palmitoleic (C16: 1) & 1.76 & 1.52 & 1.59 & 1.78 & 0.24 & 15.27 \\
\hline Oleic (C18: 1n9) & 33.51 & 33.97 & 32.96 & 33.01 & 0.77 & 5.61 \\
\hline Linoleic (C18: 2n6) & 18.84 & 18.51 & 19.89 & 19.13 & 0.77 & 12.39 \\
\hline Linolenic (C18: 3n3) & 0.41 & 0.41 & 0.48 & 0.49 & 0.86 & 45.67 \\
\hline Arachidonic (C20: 4n6) & 2.13 & 2.48 & 2.66 & 2.73 & 0.33 & 23.24 \\
\hline
\end{tabular}

${ }^{1} \mathrm{CV}$ : Coefficient of variation; Means followed by different letters on the same line are significantly different by Duncan's test at $5 \%$ probability level.

which did not differ from those in the animals supplemented with coconut oil and with ractopamine.

The higher oleic acid concentration in the evaluated cut may be associated with the better use of safflower lipids by the body, considering that safflower oil contains 16 to $20 \%$ oleic acid (TONGUC et al., 2012), whereas coconut oil contains only $5.65 \%$ oleic acid, and soy oil (used in the basal diet and with ractopamine) contains $23 \%$ oleic acid.

As for the fatty acid profile of adipose tissue, a difference $(\mathrm{P}<0.05)$ was observed only in the myristic acid content, with lower deposition in pigs supplemented with safflower oil and ractopamine.

The BRAZILIAN SOCIETY OF CARDIOLOGY (SBC, 2013) stated that saturated fats, especially lauric, myristic and palmitic acid, must be moderately consumed, because these fatty acids have a high potential to increaseL DL-C and HDL-Cand are known as hypercholesterolemic agents. Moreover, a meta-analysis by MICHA AND MOZAFFARIAN (2010) showed that lauric acid has the highest effect on increasing the LDL-C fraction, followed by myristic and palmitic acids. Therefore, a diet containing lower levels of these acids is desirable.

\section{CONCLUSION}

This study concluded that both coconut oil and safflower oil can be used to substitute ractopamine because they show similar effects on performance, carcass quality, and fatty acid profile.

\section{ACKNOWLEDGMENTS}

The authors would like to thank the Federal University of Rio Grande do Norte (UFRN), the National Council for Scientific and Technological Development $(\mathrm{CNPq})$ and the Coordination for the Improvement of Higher Education People (CAPES) for the granting of master's and post-doctoral scholarships and enabling the project.

\section{BIOETHICS AND BIOSSECURITY COMMITTEE APPROVAL}

The project was approved by the Animals Ethics Committee (AEC) under no. 002/2016.

\section{DECLARATION OF CONFLICT OF INTERESTS}

The authors declare no conflict of interest. The founding sponsors had no role in the design of the study; in the 
collection, analyses, or interpretation of data; in the writing of the manuscript, and in the decision to publish the results.

\section{AUTHORS' CONTRIBUTIONS}

All authors contributed equally for the conception and writing of the manuscript. All authors critically revised the manuscript and approved of the final version.

\section{REFERENCES}

Associação Brasileira de Proteína Animal (ABPA). Relatório anual, 2018. Available from: $<\mathrm{http}$ ://abpa-br.com.br/storage/files/ relatorio-anual-2018.pdf>. Accessed: Nov. 04, 2019.

Associação Brasileira de Criadores de Suínos. Métodos Brasileiros de Classificação de Carcaça. Estância, RS: ABCS. 1973. 17p.

ALMEIDA, V. V. et al. Ractopamina, cromo-metionina e suas combinações como aditivos modificadores do metabolismo de suínos em crescimento e terminação. Revista Brasileira de Zootecnia, v.39, n.9, p.1969-1977, 2010. Available from: <http:// www.scielo.br/pdf/rbz/v39n9/a15v39n9.pdf $>$. Accessed: Nov. 05, 2019. ISSN 1806-9290.

ASSUNÇÃO, M. et al. Effects of dietary coconut oil on the biochemical and anthropometric profiles of women presenting abdominal obesity. Lipids, v.44, n.7, p.593-601, 2009. Available from: $<$ https://aocs.onlinelibrary.wiley.com/doi/epdf/10.1007/s11745-0093306-6>. Accessed: Nov. 04, 2019. doi: 10.1007/s11745-009-3306-6.

BLANKSON, H. et al. Conjugated linoleic acid reduces body fat mass in overweight and obese humans. The Journal of Nutrition, v.130, n.12, p.2943-2948, 2000. Available from: <https://academic. oup.com/jn/article/130/12/2943/4686248>. Accessed: Nov. 05, 2019. doi: https://doi.org/10.1093/jn/130.12.2943.

BLIGH, E. G.; DYER, W. J.A rapid method of total lipid extraction and purification. Canadian Journal of Biochemistry and Physiology, v.37, n.8, p.911-917, 1959. Available from: <https://www.nrcresearchpress. com/doi/pdf/10.1139/059-099>. Accessed: Nov. 05, 2019.

BOLSONI-LOPES, A. et al. Palmitoleic acid (n-7) increases white adipocytes GLUT4 content and glucose uptake in association with AMPK activation. Lipids in Health and Disease, v.13, p.199, 2014. Available from: <https://lipidworld.biomedcentral.com/ track/pdf/10.1186/1476-511X-13-199>. Accessed: Nov. 05, 2019. doi: 10.1186/1476-511X-13-199.

BRIDI. A. M.; SILVA. C. A. Evaluation of pork. Londrina Midiograf, p.120, 2009.

CAMPANELLA, L. C. A. et al. Efeito da suplementação de óleo de cártamo sobre o peso corporal, perfil lipídico, glicídico e antioxidante de ratos wistar induzidos à obesidade. Revista de Ciências Farmacêuticas Básicas Aplicadas, v.35, n.1, p.141-147, 2014. Available from: $<$ http://serv-bib.fcfar.unesp.br/seer/index.php/Cien_Farm/article/ view/2921/1526>. Accessed: Nov. 05, 2019. ISSN 1808-4532.

COSTA E SILVA, L. C. et al. Effects of ractopamine hydrochloride and immunological castration in pigs. Part 2: belly quality characteristics and fatty acid composition. Food Science and Technology, v.37, n.3, p.404-410, 2017. Available from: <http:// www.scielo.br/pdf/cta/v37n3/0101-2061-cta-1678-457X12716. pdf>. Accessed: Nov. 05, 2019. doi: 10.1590/1678-457X.12716.
FERREIRA, A. S. et al. Ractopamine for pigs: a review about nutritional requirements. Journal of Basic and Applied Sciences, v.9, p.276-285, 2011. Available from: $<$ https://pdfs.semanticscholar. org/1a6a/d2f5a0106c9c138617ece6ebbdc923136fb1.pdf $>$. Accessed: Nov. 05, 2019. ISSN: 1814-8085.

FIGUEIREDO-SILVA, A. C. et al. Link between lipid metabolism and voluntary food intake in rainbow trout fed coconut oil rich in medium-chain TAG. British Journal of Nutrition, v.107, n.11, p.1714-1725, 2012. Available from: <https://www.cambridge.org/ core/services/aop-cambridge-core/content/view/3D69AD40ADD273 BA1082581A6DC42F73/S0007114511004739a.pdf/link_between_ lipid metabolism and voluntary food intake in rainbow trout fed_coconut_oil_rich_in_mediumchain_tag.pdf $>$. Accessed: Nov. $0 \overline{5}$, 2019. doi: $10.1017 / \mathrm{S} 000 \overline{7} 11451100473 \overline{9}$.

HARTMAN, L.; LAGO, R. C. Rapid preparation of fatty acid methyl esters from lipids.Laboratory Practice, v.22, n.7, p.475476, 1973. Available from: < https://pubs.acs.org/doi/pdf/10.1021/ ac60235a044>. Accessed: Nov. 05, 2019.

LIAU, K. M. et al. An open-label pilot study to assess the efficacy and safety of virgin coconut oil in reducing visceral adiposity. ISRN Pharmacology, v.2011, 2011. Available from: <http:// downloads.hindawi.com/archive/2011/949686.pdf>. Accessed: Nov. 05, 2019. doi: 10.5402/2011/949686.

LUCAS, R. R. et al. Herbal medicines applied to obesity. Demetra: Food, Nutrition and Health, v.11, n.2, p.473-492, 2016. Available from: <file://C:/Users/Andreza/Downloads/19154-91780-1-PB. pdf>. Accessed: Nov. 05, 2019. doi: 10.12957/demetra.2016.19154.

NATIONAL PORK PRODUCERS COUNCIL. Pork quality standards, Des Moines, IA, 1999. Available from: < https:// egashops.directedje.com/PorkStoreProducer/product-details. asp?ID=90\&CID=18\&P=1>. Accessed: Nov. 05, 2019.

OBSEN, T. et al. Trans-10, cis-12 conjugated linoleic acid decreases de novo lipid synthesis in human adipocytes. The Journal of Nutritional Biochemistry, v.23, n.6, p.580-590, 2012. Available from: <https://reader.elsevier.com/reader/sd/pii/S0955286311000891 ?token=64DFB3D07FDAAF7DD5B76CC46E5DF7C4E7A69D523 6B248069F47B6F186359F1B5D6A4A9B1561A1BF63494E926712 309A>. Accessed: Nov. 05, 2019. doi: 10.1016/j.jnutbio.2011.02.014.

ROSTAGNO, H. S. et al. Tabelas Brasileiras de aves e suínos: Composição de alimentos e exigências nutricionais. 3ed. Viçosa, MG: UFV, 2011. 252p.

SANTOS, R. D. et al. Sociedade Brasileira de Cardiologia: I Diretriz sobre o consumo de gorduras e saúde cardiovascular. Arquivos Brasileiros de Cardiologia, v.100, n.1, p.1-40, 2013. Available from: <http://www.scielo.br/pdf/abc/v100n1s3/ v100n1s3a01.pdf>. Accessed: Nov. 05, 2019. ISSN-0066-782X.

Sociedade Brasileira de Cardiologia/SBC. V Diretriz brasileira de dislipidemias e prevenção da aterosclerose. Arquivo Brasileiro de Cardiologia, v.101, p.1-22, 2013. Available from: $<$ http://www. scielo.br/pdf/abc/v101n4s1/v101n4s1.pdf $>$. Accessed: Nov. 05, 2019. ISSN-0066-782X.

TONGUÇ, M. et al. Changes in seed reserve composition during germination and initial seedling development of safflower (Carthamus tinctorius L.). Turkish Journal of Biology, v.36, n.1, p.107-112, 2012. Available from: <http://journals.tubitak. gov.tr/biology/issues/biy-12-36-1/biy-36-1-13-1012-164.pdf>. Accessed: Nov. 05, 2019. doi: 10.3906/biy-1012-164.

Ciência Rural, v.50, n.6, 2020. 